\title{
The English Language and Sustainable Development in Nigeria
}

\author{
Ifeyinwa Obiegbu \\ National Metallurgical Training Institute, Onitsha, Nigeria \\ Email: ifeyinwaobiegbu@gmail.com
}

Received 5 February 2015; accepted 23 February 2015; published 27 February 2015

Copyright (C) 2015 by author and Scientific Research Publishing Inc.

This work is licensed under the Creative Commons Attribution International License (CC BY).

http://creativecommons.org/licenses/by/4.0/

(c) (i) Open Access

\begin{abstract}
Language is the only sustainable weapon that can bind a multilingual nation like Nigeria together. The English language occupies a very significant role in the formation of national values and integration of the Nigerian nation. More than a decade after decolonization of Nigeria, English continues to enjoy its primacy in our educational system as a medium of instruction. Economically, English language is crucial for economic growth. The fragile unity that we still enjoy in Nigeria would have been herculean without the English language. This paper pointedly exposes us to the various ways in which the English language acts as a veritable tool for sustainable development in Nigeria.
\end{abstract}

\section{Keywords}

\section{Language, Decolonization, Sustainable Development, Multilingualism}

\section{Introduction}

Language and society are so much related. Their relationship cannot be underestimated. Language is the oil that lubricates activities within any human society Chomsky (1957). It is an indispensable medium that helps man to achieve effective communication as it mirrors the mind in deep and significant ways.

The English language has taken the position of a national language in Nigeria. There is no gain saying the fact that English has become a Nigerian language (Adegbite, 2004: p. 56). The language has become an invaluable legacy of the British colonial masters. Several years after independence, English still survives and has assumed a more important status in Nigeria. This paper examines English as the language education, the language of economics and the language of unity in Nigeria. These are very important avenues for meeting the much needed sustainable development that we all need in Nigeria. The importance of English language as a veritable tool for sustainable development in Nigeria forms the core of this paper. 


\section{The Language Situation in Nigeria}

The number of languages spoken in Nigeria has been variously estimated from one hundred and fifty (150) to about four hundred (400) (Bamgbose, 1991: p. 24). Everywhere in the world, there appears to be one language problem or another. All the former British colonies were left with the English language on the departure of the colonial government Sapir (1921). Nigeria has English as her official language. The use of English as the official language in Nigeria defuses ethnic conflicts and yet questions the authenticity and identifies of the users. This has always resulted in arguments about the choice of indigenous languages for official and national purposes because the use of English as our official language strikes at the root of national pride since English is a colonial language.

The Nigerian constitution stipulates that English, the language of our colonial masters and indeed a second language to Nigeria is our official language. paragraphs 51 and 91 of the 1988 Constitution of the Federal Republic of Nigeria further confirm the status of English as follows:

The business of the National Assembly shall be conducted in English language, and in Hausa, Igbo and

Yoruba when adequate arrangements have been made paragraphs 51.

The business of the State House of Assembly shall be conducted in English but the house may in addition to

English conduct the business of the house in one or more other languages spoken in the state.

(Federal Republic of Nigeria paragraph 91).

This implies that official transactions of government, administration, trade and commerce, law and justice, instruction in the education sector, should be done in the English language.

Nigerians, as a matter of fact, would have wanted to have one of the four hundred ethnic languages to be recognized as the official language. But the multiplicity of the languages poses a problem to the ethnic conscious Nigerians. The situation is a very difficult one and that is why it has been concluded that "the national language issue in Nigeria is a sensitive ad controversial one”. The reason is that each language has a geographical boundary which sees her language as a mark of social identity. The selection of one as a national language over others would bring in disagreement. The truth is that "no ethnic group wants to be subservient to another ethnic language because the promotion of the ethnic language connotes the promotion of the corresponding ethinic group itself”. Jowit also posits the need for every self-respecting nation to have a national language. This, however, seems not feasible in the Nigerian context. The English language, therefore, has come to stay in Nigeria and has established itself as the language of upward mobility in the country.

\section{The Concept of Sustainable Development}

Let us take a look at the concept of development before elucidating what its sustainability entails. In the first place, Ajibade sees "development" as a positive change for the better, from conditions (social, economic, political, cultural and human) that are no longer considered good enough for the goals and aspirations of a society, to those that are most likely to meet such goals and aspiration.

This is affirmed by the wikipedia, the on-line dictionary definition which states that sustainable development (SD) is a pattern of resource use that aims at meeting human needs while preserving the environment so that these needs can be met not only in the present, but also for generations to come.

The term was used by the Brundtland commission which coined what has become the most often-quoted definition of sustainable development as development that "meets the needs of the present without compromising the ability of future generations to meet their own needs".

The United Nations World Commission on Environment and Development (WCED) in its 1987 report "our common future" defines sustainable Development as "Development that meets the needs of the present without compromising the ability of future generation to meet their own needs”.

The United Nations World Commission on Environment and Development (WECD) Encyclopaedia Britannica (2002) in its 1987 report “Our Common Future” defines Sustainable Development as "Development that meets the need of the present without compromising the ability of future generations to meet their own needs". The Government of the Federal Republic of Nigeria is interested in sustainable development. This means making the necessary decisions now to realize our vision of stimulating economic growth and tackling the deficits, maximizing wellbeing and protecting our environment, without affecting the ability of future generations to do the same.

The government takes account of sustainable development as a part of how it develops its policies, how it runs its buildings and how it buys its goods and services. All departments are responsible for making sure that their own 
policies and activities contribute to sustainable development. The English language forms a key factor to sustainable development in Nigeria.

\section{Arguments in Favour of English as a Tool for Sustainable Development in Nigeria}

We will be looking at English language as a tool for sustainable development in Nigeria in the areas of education, economic growth and as a driving force for national unity in Nigeria.

\subsection{The Role in the Area of Education}

What should be the purpose of education? This is a question that has agitated the minds of teachers and policy makers all through the ages. The purpose of education in Nigeria is for national unity and development. This has informed many of the reform programmes of successive Nigerian governments. There have been initiatives by government on nomadic education, technical skills development, professional enhancement and continuous education among others. It is only through the English language that these basic education at different levels can be achieved. Even the nomadic education has to be done in English language because the concept to be used in teaching at a higher level (right after primary three) has to be provided in the English language.

The English language is the language of Education in Nigeria Ndimele (2006). Apart from the first three years of a child's life in the primary school that was mentioned in the National Policy on Education, the rest of the child's life in the primary, secondary and tertiary institutions, all academic activities must be done in the English language. English is the language of prestige per excellence and a firm knowledge of it is an assurance of climbing the educational ladder of success in Nigeria. Credit in five subjects including English and mathematics in the West African School Certificate is a passport to any Nigerian university and subsequently offers a speedy access to employment in the job market.

Before development can come to a people, there must be a means of communication and language quickly comes to play Browny (1987). Considering the many indigenous languages present in Nigeria today, it is quite difficult to impose an indigenous and unifying language because they number over four hundred. The language scenario in Nigeria would have been close to what happened at the Tower of Babel had not a foreign language, English, been introduced and used in the country.

\subsection{Economic Growth}

Economically, English language is the avenue to sustainable development in Nigeria. Economists in Nigeria believe that English is crucial for economic growth, as it helps them trade more widely on an international scale. Nigeria can do international businesses because we have English as our official language. The international community can easily and comfortably be reached because of the prestigious language. English is very important when hiring a new employee. This underlines the fact that English language skills enhance business and trade, while also improving an individual's economic conditions.

An individual's economic empowerment in Nigeria is closely linked with good command of English. A wide range of business categories in Nigeria including the banking industry, technology, the pharmaceutical industry, and even vocational workers such as carpenters and electricians see increased need for English language skills. A salaried professional with good English language skills can earn an average of thirty percent (30\%) more than someone with no English language skills in Nigeria. The government of Nigeria firmly recognized that English is a key element of business communication and it is essential for attracting new investments. With government and companies pushing for far more English speaking workers, it can be expected that more individuals will view English, among other skills, as a step towards career advancement and higher pay. This is a motivating factor for individuals to learn English in order to obtain well-paid jobs within the most dynamic organizations and industries in Nigeria. Clearly, we all can see that prospective employees who can speak and write English well have better opportunities economically. This way, English language is a tool for sustained national development.

\subsection{National Unity}

English language serves as a tool for sustainable development in the area of national unity in Nigeria. Amidst the compounding complexities and wars in the northern part of Nigeria, the only language that still emits the spirit of 
oneness in Nigeria is the English language. More often than not, activities conducted in indigenous languages are seen as being ethnic or tribal, except in cultural celebrations or ethnic displays. This explains why, even during the first republic and during the colonial era, when English had not attained its present level of ascending in national and international affairs, political parties were formed in English language. However, the parties might have regional bases but the fact that they were named in English entailed their national identity. The Northern People's Congress (NPC), The Action Group (AG), The National Council of Nigeria Citizen (NCNC) after the excision of Southern Cameroun, National Elements Progressive Union (NEPU) etc, were formed to integrate all Nigerians and give them a sense of belonging. This trend has necessarily survived until today with all the national political parties formed and sloganeered in English.

English is equally the language of nationalism Hanna (2008). The love of a country has to be manifested through the language that everybody can understand lest the ethnic agenda be implied. This was why, even in the old political days, nationalists like Herbert Macaulay, Obefemi Awolowo, Ahmadu Bello, Nnamdi Azikiwe etc. had to use English language as a weapon of nationalist struggle. A nationalist bases his patriotic views in English. If English language is not used to express the same ideas for which he is known as a nationalist, he is seen instantly as a tribalist and not a nationalist. English is the language of authenticity in Nigeria.

Collective identity of Nigeria is stamped on national institutions through the medium of English language. The Army, the Navy, the Air Force, and the Police, that all safeguard the territorial integrity of Nigeria and its peaceful existence is propelled with English language (Standard British English and Pidgin English). The National Youth Service Corps (NYSC) which is aimed at bringing together all the educated Nigerian youths from the universities is a great ideal of the Nigeria government. This ideal would not have been possible without the English language which binds all together at the camps and at their primary places of assignment. The idea of the National Youth Service Corps is geared towards reinforcing the spirit of oneness among Nigerian youths. However, on-going challenges of security and national unity which the vicious Boko Harams have caused in the northern part of Nigeria are causing a lot of threat to this good scheme of the Nigerian government because the youths are now afraid to go to the northern part of the country for the service scheme. We believe that with providence on our side, the English language will continue to bind us together.

The constitution of the Federal Republic of Nigeria is written in English to create a level playing ground for all Nigerians. The National flag, the National Anthem, the National Independence Day, the National Associations as well as several national monuments are designed in English and all of these "assert" that English is the foundation of the giant structure called Nigeria. All these have the effects of reducing what (Adebayo, 1985: p. 2) refers to as "deep rooted mutual suspicion that result in prejudice, stereotypes and subtle linguistic hostility among various linguistics groups”. English language remains a very big tool in favour of sustainable development in Nigeria.

\section{Concluding Observations}

The best form of education is the one that opens our minds to think critically, our hearts to embrace all even when we disagree and our hands to be practical in all endeavors. Nigerian problems can only be solved through a purpose laden education in English language that is desired by all and sundry Obuasi (2006). If the idea of sustainable development is to create a system that is sustainable, which means that one can keep going indefinitely into the future, then the English language becomes a key factor to unending development in Nigeria in the areas of education, economic empowerment and national unity.

\section{References}

Adebayo, A. J. (1985). Language, National Integration and the Nigerian Federation. Edinburgh: Edinburgh University Press.

Adegbite, W. (2004). Bilingualism, Briculturalism and Utilization of African Languages for the Development of African Nations. Ibadan: Hope Publications Ltd.

Bamgbose, A. (1991). Language and the Nation. The Language Question in Sub-Sahara Africa. England: Englewood University Press.

Browny, H. D. (1987). Politics of Language Learning and Teaching. Englewood Cliffs: N.J. Practice Hall.

Chomsky, N. (1957). Language. The Properties of Human Language. Oxford: Education Press.

Encyclopaedia Britannica (2002). The Dynamics of Language and Societal Stability. Cambridge: University Press.

Hanna, O. (2008). Language as a Tool for National Integration: The Case of English Language in Nigeria. International 
Journal of the Sociology of Language, 3, 21-32.

Ndimele, O. M. (2006). Four Decades in the Study of Language and Linguistics in Nigeria, A Fest Schrift for Kay Williams. Aba: National Institute for Nigeria Languages.

Obuasi, I. (2006). The Place of Language in Nigeria's Reform Agenda. Nsukka: UNN Press Ltd.

Sapir, L. (1921). The Meaning of Language Theory and Practice. Washington DC: USA Centre for Applied Linguistics. 
Scientific Research Publishing (SCIRP) is one of the largest Open Access journal publishers. It is currently publishing more than 200 open access, online, peer-reviewed journals covering a wide range of academic disciplines. SCIRP serves the worldwide academic communities and contributes to the progress and application of science with its publication.

Other selected journals from SCIRP are listed as below. Submit your manuscript to us via either submit@scirp.org or Online Submission Portal.
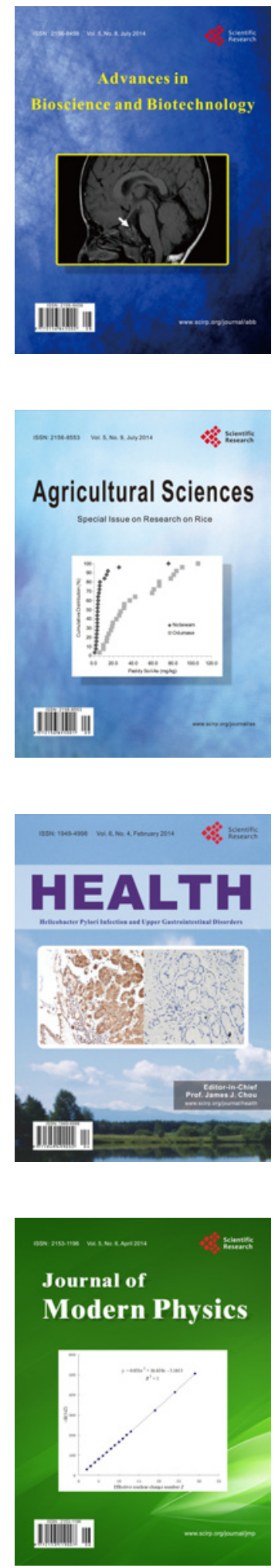
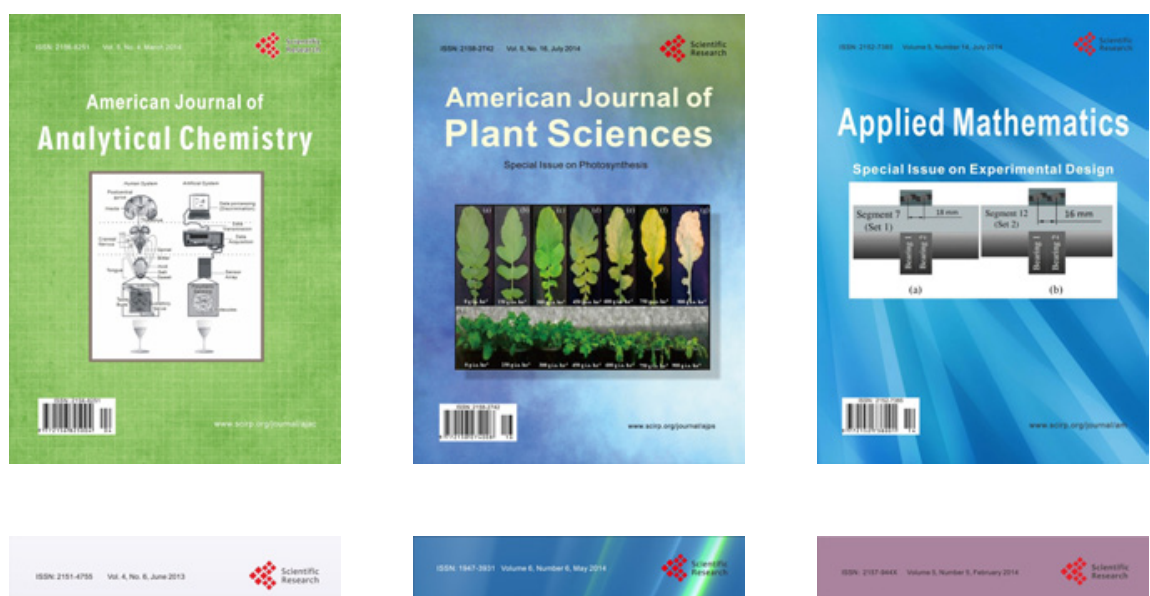

Creative Education
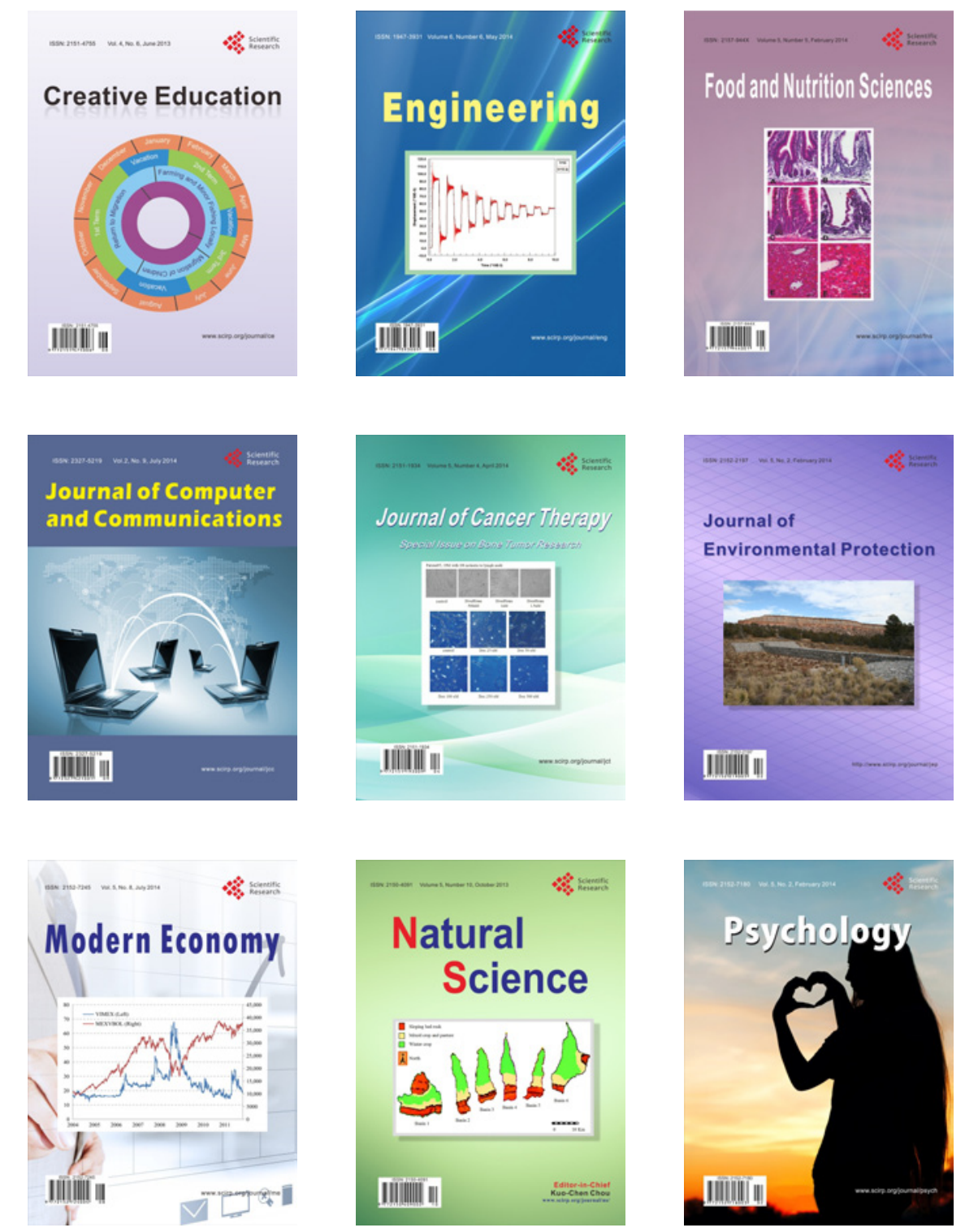